\title{
CHARACTER EDUCATION VALUES IN HANAN ATTAKI'S MILLENNIAL DA'WA
}

\author{
Nasihatul Latifah ${ }^{1}$, Lilik Huriyah ${ }^{2}$, Nuwailah R. Rufqoti ${ }^{3}$, Rohil Zilfa ${ }^{4}$ \\ 1,2,3Sunan Ampel State Islamic University Surabaya, ${ }^{4} \mathrm{High}$ School of Islamic Education Jembrana Bali \\ 1nasi_hatul@yahoo.co.id, 2lilikhuriyah@uinsby.ac.id, ${ }^{3}$ nailah.ridh@gmail.com, ${ }^{4}$ rohilzilfa@yahoo.com
}

\begin{abstract}
The purpose of this research is to describe the da'wa profile of Ustadz Hanan Attaki, the values of character education in the da'wa material of Ustadz Hanan Attaki's millennial da'wa, and the advantages and disadvantages of Ustadz Hanan Attaki's millennial da'wa. This research is a qualitative content analysis research. The unit of analysis in this study were three videos of Ustadz Hanan Attaki's lecture uploaded on the YouTube shift channel with the title Beautiful morals of Rasulullah, the Hijrah TV channel with the title Learning Morals from the Prophet Muhammad, and the YouTube channel Salamulqolbi Channel with the title High Morals of Rasulullah saw. The results of this study state that the da'wa of Ustadz Hanan Attaki is a mission that serves to create millennials with digital media. The values of character education in the millennial da'wa of Ustadz Hanan Attaki are character education for honesty, tolerance, respect, courtesy, responsibility, leadership, and fairness. The advantages of the da'wa of Ustadz Hanan Attaki are that the language and terms used are very close and suitable for the millennial generation, the material for da'wa is delivered in a relaxed and flexible way, and the da'wa media of Ustadz Hanan Attaki can be accessed very easily. While the weakness is that some of the terms used are rather difficult to be translated by the old generation.
\end{abstract}

Keywords: Character education values, millennial da'wa, Hanan Attaki.

\begin{abstract}
Abstrak:
Tujuan penelitian ini adalah untuk mendeskripsikan profil dakwah ustadz Hanan Attaki, nilai-nilai pendidikan karakter dalam materi dakwah milenial ustadz Hanan Attaki, serta kelebihan dan kekurangan dakwah milenial Ustadz Hanan Attaki. Penelitian ini adalah penelitian analisis isi kualitatif. Unit analisis pada penelitian ini adalah tiga video ceramah ustadz Hanan Attaki yang diunggah pada kanal youtube shift dengan judul Indahnya Akhlak Rasulullah, kanal Hijrah TV dengan judul Belajar Akhlak dari rasulullah saw, dan kanal youtube Salabulqolbi Chanel dengan judul Tingginya Akhlak Rasulullah saw. Hasil penelitian ini menyatakan bahwa dakwah ustdaz Hanan Attaki termasuk dakwah yang ditujukan untuk generasi milenial dengan media digital. Nilai-nilai pendidikan karakter dalam dakwah milenial ustadz hanan Attaki adalah pendidikan karakter jujur, toleransi, hormat, santun, tanggungjawab, kepemimpinan dan adil. Adapun kelebihan dari dakwah ustadz Hanan Attaki adalah bahasa dan istilah yang digunakan sangat dekat dan cocok dengan generasi milenial, materi dakwah disampaikan dengan cara santai dan fleksibel, serta media dakwah ustadz Hanan Attaki bisa diakses dengan sangat mudah. Sedangkan kekurangannya adalah beberapa istilah yang digunakan agak sulit dipahami oleh generasi lama atau para orang tua.
\end{abstract}

Kata Kunci: nilai-nilai pendidikan karakter, dakwah milenial, Hanan Attaki 


\section{A. Introduction}

In the last few years, we have encountered a lot of bad morals from young people. Such as student quarrels, anarchist demonstrations, stressful teens and suicides, young men killing their girlfriends, grandmothers, fathers, and even their mothers. Why did this happen? Allegedly, one of the reasons that these youths do not have Islamic morals is because they rarely listen to advice, lectures, or invitations to increase their faith, behave in a noble manner according to Islamic teachings.

Hanan Attaki is here to answer the needs of teenagers or the millennial generation (they were born between the 1980s and 2000s) from various backgrounds to be embraced and learn together about Islamic morals. Da'wah in the slang language of young people, the target of the millennial generation, youtube media, and joining youth clubs is Attaki's millennial da'wah model.

Inculcating character education for young people is also the main concern of the Indonesian government officially. ${ }^{1}$ This can be seen from the implementation of the 2013 Curriculum which includes character education. ${ }^{2}$ Character education is the spirit that is cultivated in every learning process in the classroom. Even, in the K-13 which is implemented in present time emphasizes on the character education which then leads all subjects in the school to contribute directly on the formation of the students' character. The curriculum contribution on the students' character formation is put on the core competency religious character and social attitude. Therefore, the formation of a student's characters, both religious and social character becomes an indicator of the success of curriculum implementation in the school. ${ }^{3}$

Various ways of internalizing character education are carried out, this is because the inculcation of character education values for millennials and adolescents is very important. ${ }^{4}$ Adolescence is a period of development, a period of transition from children to adolescents. Psychologically, teenagers have learned to make choices and determine it. Teenagers often show unstable characters. A stable and established character can be formed after habituation of attitudes and behaviors accompanied by family and social controls and the realization of both general and religious knowledge in their daily lives. Islamic teaching has a long history of developing human attitudes, emotions and character towards the highest degree of glory through moral education. Prophet Muhammad SAW was sent as the messenger of Allah in order to improve human morals. In all Islamic teachings, morals occupy a special and very important position. ${ }^{5}$ This is why it is very important to need preachers who teach Islamic teachings, which are close and can be accepted easily among teenagers and millennials. ${ }^{6}$

The existence of preachers who inculcate character education among young people is very important Millennial generations, in all ways and lifestyles of their time, need someone who directs their life to have good character, noble morals. Da'i (preacher), who knows and understands the local culture of the local millennial generation, is a new breakthrough choice for the world of Indonesian Islamic da'wah. ${ }^{7}$ Millennials who live in modern times demand da'wah

\footnotetext{
${ }^{1}$ Suyatno, et.al., Design of Values Education in School for Adolescent, Anlatis Press, Anvances in Social Science, Education and Humanities Research, 2017, Volume 134.

${ }^{2}$ Dian Ikawati Rahayuningtyas, et.al., Analisis Muatan Nilai Karakter pada Buku Ajar Kurikulum 2013 Pegangan Guru dan Siswa Sekolah Dasar, Jurnal Pendidikan Karakter, 2018, Tahun VIII, Nomor 2, 123139.

${ }^{3}$ Suyatno, et. al., "Strategy of Values Education in the Indonesia Education System," International Journal of Instruction, January 2019, Vol. 12. No. 1.

${ }^{4}$ Alima Fikri Shidiq, Santoso Tri Raharjo, Peran Pendidikan Karakter di Masa Remaja sebagai Pencegahan Kenakalan Remaja, Prosiding Penelitian \& Pengabdian kepada Masyarakat, 2018, Vol. 5. No. 2, 176-187.

${ }^{5}$ Fitroh Hayati, Pendidikan Karakter Berbasis Islam, Ta'dib: Jurnal Pendidikan Islam, Vol. 7 No. 1 (2018), 425-433.

${ }^{6}$ Siti Maryam Munjiat, Peran Agama Islam dalam Pembentukan Pendidikan Karakter Usia Remaja, $A l$ Tarbawi Al Haditsah: Jurnal Pendidikan Islam, Vol 3. No. 1, Juni 2018.

${ }^{7}$ Salsabilah, Pendidikan Karakter Islami Berbasis Nilai-Nilai Kearifan Lokal, Cendekia, 2019, Vol. 17, No. 2.
} 
in modern ways. Modernization has become part of the journey of time and space that has been, is being and will be passed by the world community.

This phenomenal change in society should be balanced with a change in the way of preaching carried out by $d a^{\prime} i$ (preachers). Da'wah is not appropriate to stuck using conventional methods (lectures on the pulpit only). Da'wah must be dynamic, progressive and full of innovation. The fast flow of information and technology in the world produces various dynamics of scientific development, including Islamic preaching and communication. The emergence of new theories, concepts, and terms in the science of $d a^{\prime} w a h$ is an indicator and scientific effort of $d a^{\prime} w a h$ in responding to the challenges of the times. ${ }^{8}$

$D a$ 'wah in the millennial era, for millennials generation, you must be digitally literate. $D a$ 'wah content will be more attractive to the millennial generation if there are virtual elements such as quotes, memes, script comics, infographics, and videos along with the vlog trend. 9 $D a$ 'wah material is delivered in the language of the millennials, summarized, recorded, and uploaded on the YouTube page, so that it can be seen and listened to repeatedly whenever the millennial generation wants to see and hear it. ${ }^{10}$ For the millennial generation, social media is more likely to be used for watching videos and youtube than for socializing. Thus, digital preaching for the millennial generation will be very urgent and crucial at this time. ${ }^{11}$

This study aims to describe the preaching profile of Ustadz Hanan Attaki, examine the values of character education in the preaching material of Ustadz Hanan Attaki's millennial $d a^{\prime} w a h$, and to find the advantages and disadvantages of Ustadz Hanan Attaki's millennial preaching.

\section{B. Theoretical Review}

The preachers in the millennial era are required to be able to adapt, contribute, including: being able to develop information systems. This information system can develop data-based systems. The data here can be in the form of audiences and da'wah material. Besides that, the $d a^{\prime} i$ also have to train their followers to develop the ability to receive, store, process, and convey information. So that communication is very important in the curriculum.

Furthermore, the preachers $\left(d a^{\prime} i\right)$ as successors to the Prophet Muhammad should not act passively. The various challenges faced by the $d a^{\prime} i$ must be given a good solution planning. Our love for the legacy of the salaf scholars has not caught us off guard in preparing for the future. More than that, preachers must be able to carry out therapeutic (healing) $d a^{\prime} w a h$ movements because people are easily stressed out in this era of rapid flow of information. So the function of the $d a^{\prime} i$ here is not only as an educator, but also as a doctor. Next, the challenge for the $d a^{\prime} i$ is tough competition with other entertainment agencies. The preachers must be clever in packaging their $d a^{\prime} w a h$ by utilizing the latest communication technology (Rakhmat, 1991: 7075). ${ }^{12}$

The thing that needs more attention nowadays for preachers is the material given to the audience, especially for the millennial generation. The thing that needs to be emphasized to the millennial generation is character education, good morals. Character education is defined as equal value education, character education, moral education, character education, or moral

\footnotetext{
${ }^{8}$ Abdul Ghofur, Dakwah Islam di Era Millenial, Dakwatuna: Jurnal Dakwah dan Komunikasi Islam, 2019, vol. 5, No. 2, 136-149.

${ }_{9}$ Anang Walian, Pengembangan Media Dakwah Kontemporer berbasis Website: Studi Kasus pada www.assajidin.com, Jurnal Komunikasi Islam dan Kehumasan (JKPI), 2019, Vol. 3. No. 1, 1-21.

${ }^{10}$ Enjang Muhaemin, Dakwah Digitas Akademisi Dakwah, Ilmu Dakwah: Academic Journal for Homeletic Studies, 2017, Vol. 11., No.2, 341-356.

${ }^{11}$ Ayu Kristina, Dakwah Digital untuk Generasi milenial: Studi Atas Praktik Dakwah di Komunitas Omah Ngaji, Surakarta, Borneo Undergraduate Academic Forum (BUAF) 2019.

12 Enjang Muhaemin, Dakwah Digital Akademisi Dakwah, Ilmu Dakwah: Academic Journal for Homeletic Studies, 2017, Vol. 11., No.2, 341-356 dan J. Rakhmat, Islam Aktual., Mizan, Bandung, 1991.
} 
education which aims to develop the ability of students to make good and bad decisions, maintain what is good, and fully realize that good in everyday life day full heartedly. Therefore, character education can be broadly defined as education that develops cultural values and character as his character, applies these values in his life as a member of society, and a religious, nationalist, productive, and creative citizen (Ainiyah, 2013,27).

\section{Methods}

Make sure that the work can be repeated according to the details provided. It contains This research uses a qualitative discourse analysis research approach. The analysis unit of this research is 4 videos of Ustadz Hanan Attaki's millennial da'wa. The first video is entitled "The Morals Features of The Prophet Muhammad PBUH". This da'wa was delivered on Wednesday, February, 28 2018 in The Grand Mosque of Trans Studio Bandung Jl. Gatot Subroto no. 289 Bandung and uploaded to Youtube channel Kajian Islam News. The second video is entitled "Learning Exemplary from The Prophets" in the Youtube channel Motive Islam which was uploaded on July, $8^{\text {th }}$ 2020. The third is video entitled "The Story of Rasulullah, The Brave and Humble" in the Youtube channel Kajian Islam Harian which was uploaded on February, $2^{\text {nd }} 2020$. The last video is entitled "The Beautiful Morals of the Prophet PBUH" on the Dunia Bumi Youtube Channel which was uploaded on April 28th 2020.

Collecting data by listening and recording. The author listens to 4 videos of Ustadz Hanan Attaki's millennial da'wah youtube, then notes things that contain the value of character education and da'wah material of Ustadz Hanan Attaki, the strengths and weaknesses of the 4 videos, and records sentences or terms that are difficult to understand by certain listeners in this case, other than the millennial generation or parents. The reliability of this data the writer uses an intrawriter and an interwriter. The intrawriter repeated in the process of seeing and listening to 4 youtube videos of Ustadz hanan Attaki's millennial da'wah. Meanwhile, the reliability of the interwriters was done by a Focus Group Discussion (FGD) with experts to see if the research data was correct.

The data analysis of this research uses Miles and Huberman data analysis (2014), namely data condensation (retrieving important data), data display, and inference (summarizing data).

\section{Results and Discussion}

Ustadz Hanan Attaki's Millennial Da'wah which is meant here is the da'wa carried out by Ustadz Hanan Attaki that is aimed to the Millennial generation, youth, such as children of motorcycle gangs, BMX club, bikers, skateboard clubs, and other youth clubs. The material of Ustadz Hanan Attaki's da'wah is more about morals, rather than on fiqh. The language used in the da'wah of ustadz hanan Attaki is youth slang, which is very close to the language of applications, electronics, mobile phone features and applications, the latest films, Basket Ball figures, and other figures who are very familiar among young people or the millennial generation. In this research, the author revealed 4 videos of Ustadz Hanan Attaki's millennial da'wah which were uploaded on the YouTube channel Kajian Islam News, Motive Islam, Kajian Islam Harian, and Dunia Bumi.

Based on the research data that has been processed by the author, it can be stated that there are values of character education conveyed in Ustadz Hanan Attaki's lecture from 4 videos, namely video 1 "The Morals Privilege of The Prophet Muhammad PBUH", Video 2 "Learning Exemplary from The Prophets", Video 3 "The Story of Rasulullah, The Brave and Humble", and video 4 "The Beautiful Morals of the Prophet PBUH" as shown in table 1. 
Table 1. The Character Education Values in Ustadz Hanan Attaki's Millennial Da'wa

\begin{tabular}{|c|c|c|}
\hline No & Ustadz Hanan Attaki's Millenial Da'wah & $\begin{array}{l}\text { The Character Education } \\
\text { Values }\end{array}$ \\
\hline 1 & $\begin{array}{l}\text { Video } 1 . \\
\text { Title "The Morals Features of The Prophet Muhammad } \\
\text { PBUH" } \\
\text { Da'wah which was delivered on Wednesday, February 28th } \\
2018 \\
\text { In the Grand Mosque of Trans Studio Bandung } \\
\text { Jl. Gatot Subroto no. } 289 \text { Bandung } \\
\text { Youtube channel Kajian Islam news }\end{array}$ & $\begin{array}{l}\text { 1. Respect the feelings of } \\
\text { others } \\
\text { 2. Respect others } \\
\text { 3. Be brave }\end{array}$ \\
\hline 2 & $\begin{array}{l}\text { Video } 2 . \\
\text { Title "Learning Exemplary from The Prophets" } \\
\text { Youtube channel Motive Islam. } \\
\text { Uploaded on July, } 8^{\text {th }} 2020 .\end{array}$ & $\begin{array}{l}\text { 1. Be wise } \\
\text { 2. Gentle } \\
\text { 3. Be patient } \\
\text { 4. } \text { Respecting others }\end{array}$ \\
\hline 3 & $\begin{array}{l}\text { Video } 3 . \\
\text { Title "The Story of Rasulullah, The Brave and Humble" } \\
\text { Youtube channel Kajian Islam Harian. } \\
\text { Uploaded on February, } 2^{\text {nd }} 2019\end{array}$ & $\begin{array}{l}\text { 1. Be brave } \\
\text { 2. Respecting others } \\
\text { 3. Be humble } \\
\text { 4. Likes to help others }\end{array}$ \\
\hline 4 & $\begin{array}{l}\text { Video } 4 \\
\text { Title "The Beautiful Morals of the Prophet PBUH" } \\
\text { Youtube channel Dunia Bumi } \\
\text { Uploaded on April, 28th } 2020\end{array}$ & $\begin{array}{l}\text { 1. Not being arrogant } \\
\text { 2. No prestige } \\
\text { 3. Respect the opinions of } \\
\text { others } \\
\text { 4. Be encouraged to } \\
\text { admit mistakes } \\
\text { 5. Accept other people's } \\
\text { advice } \\
\text { 6. Low profile } \\
\text { 7. Respect other people's } \\
\text { feelings. }\end{array}$ \\
\hline
\end{tabular}

The values of character education in the millennial da'wah of Ustadz Hanan Attaki can be seen in the four videos, namely: (1) Respect for others, (2) Be brave, (3) Be wise, (4) Gentle, (5) Be patient, (6) Be humble, (7) Not arrogant, (8) Accepting other people's advice, (9) Be encouraged to admit mistakes, (10) Low profile.

The character of respecting others is contained in the narrative of the da'wah of Ustadz Hanan Attaki in videos 1,2,3, and 4. In video 1, Ustadz Hanan Attaki explains that the Prophet Muhammad saw really respected for others. This is reflected in the prophet's behavior when he dreamed. The prophet dreamed of entering heaven and seeing a beautiful palace. Next to the palace, there was a girl playing on a swing. The Prophet PBUH asked: "Jibril, whose palace is that?", Jibril answered: "That was Umar's palace". Then the Prophet's view was immediately turned to another direction. Though it was still a dream. The next day, the Prophet met Umar r.a. The Prophet told Umar that he dreamed of going to heaven and seeing Umar's palace. Beside the Palace, there was a girl playing on the swing. Then the Prophet Muhammad apologized to Umar, because he had a glimpse of the girl beside Umar's palace r.a. who played the swing. The Prophet took great care and respect for Umar's feelings. However, Umar did not take heart or was even angry. The Prophet took great care and respect for Umar's feelings.

The value of character education is also seen in the 2nd video. Ustadz Hanan Attaki gave an example of the character of respecting other people that was done by the Prophet. When the The Prophet prayed, there was a jin who disturbed him. The Prophet was not at all disturbed. 
Even after he finished praying, the jinn were held by the Prophet and then his hands tied and put in one of the mosques. Then the next day, the jinn were kicked like a ball by small children. Then the Prophet remembered the prayer of Prophet Sulaiman: "O Allah, give me a very broad power, which you do not give to anyone after me". Therefore, the Prophet took off the jinn from the children's kicks.

Character education to respect others is also seen in video 4. In the da'wah, Ustadz Hanna Attaki exemplifies the morals of the Prophet Muhammad who really respects the feelings of Aisyah r.a. It is said that one day, Hafshah, the wife of the Prophet Muhammad PBUH held a meal. Without Hafshah's knowledge, Aisyah came to the event. When Aisyah sat in a far corner, the Prophet knew that the veiled woman was Aisyah. Aisyah realized that the Prophet knew her coming, so Aisyah immediately ran home. The Prophet chased Aisyah and finally returned home together. On the way, Aisyah asked the Prophet Muhammad PBUH "O Rasul, if you are a shepherd, there are two meadows, one has been used by another shepherd before, and the other has not been used by another shepherd, which one do you choose? Rasulullah understood Aisyah's signal asking about the analogy of herself and the other prophet's wives. Aisyah is the only wife of the Prophet who is still rowdy. Meanwhile, all the other wives of the Prophet were widows. The Prophet answered: I like meadow where there is no shepherd. This was done by the Prophet because he kept Aisyah's feelings.

The second character education values in the millennial da'wah of Ustadz Hanan Attaki is brave character. This can be found in video 3. It is said that the Prophet had a sword held in his neck by an enemy of the disbelievers, when the Prophet sat resting away from his companions. "Muhammad, now you are far from your friends, if I cut your throat, who will help you?", asked the infidel. The Prophet smiled and calmly answered: "Allah". Hearing the Prophet's firm answer, the disbeliever immediately trembled and his sword fell. The Prophet took his sword and pointed it at the owner of the sword, asking, "Now who wants to help you?". He replied: "You are, Muhammad". Then the Prophet returned the sword to the disbeliever and was not afraid of being stabbed again. Then the disbeliever sat down with the Prophet, and consulted the matters of his life. Then the infidel went home and invited people in his area to convert to Islam.

A brave character is also recounted in video 3. One night the Prophet Muhammad was fighting with the devil in the desert. All the friends who heard the scary voice coming from the middle of the dark desert, Umar r.a. and other friends, came out of the house and gathered in front of the mosque, asking each other about the source of this gripping noise. Suddenly the sound stopped and came out of the darkness of the desert night, a person who was riding a horse, with pants and without clothes, drawing a sword. It turned out that it was the Messenger of Allah who came. after tethering his horse, the Prophet came to his companions. The companions asked, "What is it, Rasulullah?". The Prophet only replied: "It's done, it's done". Here the Prophet was a very brave figure, where he fought against Satan alone in the middle of the desert at night without a single friend to help him.

The third character education value is wise. This character is contained in Ustadz Hanan Attaki's lecture material in video 2 entitled "Learning Exemplary from the Prophets -Ust. Hanan Attaki, Lc." In his da'wah material, it was stated that the prophet Sulaiman, the son of the prophet Daud, was a figure who was known to be very wise in mastering two realms, namely the jinn and the human realm. The fourth character is gentle. This is contained in video 2 . Ustadz Hanan Attaki tells about the character of the prophet Yahya a.s. who is famous for being gentle. Furthermore, the fifth character education is be patient. This is contained in the da'wah of Ustadz Hanan Attaki in video 2. He gave an example of the patience of the prophet Nuh who preached for 950 years and only got less than 100 followers.

The sixth values of character education is being humble, not being arrogant, accepting other people's suggestions. This can be found in video 4 entitled "The Beautiful Morals of The Prophet PBUH", mentioned in video 4 that "Laqod kaana lakum fi rasulillahi uswatun hasanah". Rasulullah is an example not only in his good behavior but also in his behavior when he was wrong or forgot. Once upon a time the Prophet prayed and was wrong in counting the raka'at. 
Rasulullah prayed 2 raka'at then salam, which should had been 4 raka'at then salam. Then the Prophet discussed with the friends who became the congregation, and the Prophet added two more cycles of prayer, followed by sahwi and ended by salam. With great humility the Prophet Muhammad PBUH admitted that his raka'at was lacking, and he was not arrogant even though he was a Messenger. He accepts opinions, suggestions, and input from his friends.

The next character education values are being encouraged to admit mistakes and having a low profile. This is reflected in the asbabun nuzul, the rise of the Surah 'Abasa. Half of the surah of Surah 'Abasa are verses of the rebuke of Allah to the Messenger of Allah. Allah rebuked the Messenger of Allah when, Abdullah, who was blind and poor, wanted to study Islam from the Prophet. At that time the Prophet was teaching Islam to the community leaders. The Prophet thought, there was another time for Abdullah. Allah says "kalla" (don't be so) "innaha tadzkiroh" (This is a lesson for those people). Abdullah left; the Prophet chased him but did not find him. Then the Prophet gathered his companions and recited the verse that had just come down, Surah 'Abasa, which is Allah's admonition against him. A few days later, when Abdullah came, the Prophet spread his turban and said "Welcome to the person who because of him, I am rebuked by Allah". The Prophet acknowledged his mistake, thanked Allah for rebuking him, and respected the person for whom he was reprimanded by Allah. From this story, the Prophet was very encouraged to admit his mistakes and low profile. Allah's reprimand to the Prophet can be seen completely in the Qur'an, Surah 'Abasa: He (Muhammad) frowned and turned his attention away, (1). Simply because the blind man (Abdullah bun Ummi Maktum) came to him interrupting (2). You never know (Muhammad), perhaps he may be purified, (3). Or he may be mindful, benefitting from the reminder (4). As for the one who was indifferent (Quraish leaders) (5). You gave him your undivided attention, (6). Even though you are not to blame if he would not be purified. (7). But as for the one who came to you, eager to learn, (8). While he was afraid (of Allah) (9). You just ignore it (10). For once, don't (like that) Really, (Allah's teaching) is a warning (11). So, whoever wills, of course he will pay attention to it (12).

Furthermore, this research describes the advantages and disadvantages of Ustadz Hanan Attaki's millennial $d a^{\prime} w a h$. The strength of the millennial $d a^{\prime} w a h$ of Ustadz Hanan Attaki is that it is very acceptable for young people or the millennial generation. Millennial generation is a generation born in the 1980s to 2000s. The visitors of Ustadz Hanan Attaki's da'wah event in Bandung were young people from among members of the Bikers, BMX, Motorbikers, surfing clubs, and others. The millennial $d a^{\prime} w a h$ of Ustadz Hanan Attaki is uploaded on various YouTube channels so that it is very easy to be accessed by anyone, anytime, anywhere. The material presented revolves around morals, does not discuss fiqh, which usually has differences of opinion in it. So that the material is immediately practical to invite young people to migrate to be better and better in behavior.

While the weakness of Ustadz Hanan Attaki's millennial da'wah is that the recipients of da'wah tend to be only young people, or modern people. Parents who are not modern cannot follow the style of the lecture of Ustadz Hanan Attaki. Hanan Attaki often uses contemporary terms that old parents do not understand. This is as seen in video 1 . The difficult sentences in video 1 are (1) Allah mentestimoni nabi. Allah memuji nabi. (2). Semua nabi kalau posting pasti 'ngemention' nabi. (3). Rasululullah saw menjadi hastag para anbiya', \#nabi terakhir. (4). 'kriteria' akhlaknya sangat berpotensi untuk dicintai para malaikat. (5). Allah memanggil kita dengan "nada dering telepon" tangisan anak anak anak di syuriah, palaestina, rohingya, serta anak- anak di camp perbatasan yang belum "terregister" untuk mendapatkan bantuan dana dari pemerintah turki. (6). ada seorang gadis yang "order" rental mobil dengan 'driver' yang serem. (7). Allah menghidupkan Keledai nabi Uzair dari tulang belulang yang sudah mati menjadi hidup kembali setelah seratus tahun meninggal tanpa "aplikasi editan". (8). Mari kita Tajdid, perbaruan iman, 'recharge' iman dengan baca ayat Allah, dengar nasihat orang, ciptaan Allah disekitar kita dengarkan kisah sekitar kita. (9). Di'cancel' lagi bantuan yang akan datang ke kita saat kita tidak berhusnudzon pada Allah. 
Likewise, in video 2 , there is also a sentence that is very familiar to millennial ears, but it is difficult for the parents who are not modern. It is like the following sentence: (1) Nggak bisa tidur, kalau melihat "IG nya mantan". (2). Nama kita akan 'dimention' oleh Allah dilangit. Di 'add' hanan 'underscore' attaki. Untuk yang belum 'follow'. 'Modus' ini. (3). Setiap hari pada 'ngepoin' yusuf. Yusuf menjadi 'trending topic'. Orang sekarang mencari tahu sesuatu melalui 'gadget'. (4). Sarah istri Ibrahim lagi 'traveling' dari Irak ke palestine. 'Transit' di mesir. 'Connecting flight' Sarah di 'cancel'. (5). Nabi Musa 'low profile'. Kita 'zero pack'. Nabi Musa 'sixpack'. (6). Nabi musa nggak 'nge-block', 'nge-delete' 'comment' para umatnya. Yang penting gue nggak 'follow'. (7). Musa juara 'ultimate fight'. Memukul batu sampai hancur. (8). Para malaikat ingin mendengar 'Acapella solo, Tunggal show' suara merdu bacaan al Qur'an Abu Musa al Asy'ari. (9) Bahkan suara Nabi Daud sangat merdu, keren sekali hingga seperti di 'Tomorrow land brazil'. Suranya keren daripada orang nge'DJ'. Layaknya 'One-minute booster' memakai 'backsound'. Pasti 'follower'nya milyaran. (10). Jin menyuruh jin lain untuk menghalangi dakwah nabi. Jin nya di'japri' belum di'replay', telpon di'reject'. Wa di 'read' doang. (11). Nabi menghadiri seminar jin. Rasul berangkat ke 'stage'. Rasul dikelilingi jin. Lebih seruuu sekali daripada 'Harry Potter Lord of the Ring'. Jin lagi 'dinner'. Rasulullah lagi sholat digodain sama 'newbie' jin. (12). Shofiya, setelah 'sweet seventeen' menikah sama Rasulullah.

The sentences that are familiar among the millennial generation, but difficult to understand for parents who are not modern are as follows: (1). Kalau jaman sekarang mungkin para sahabat minta 'selfie' dengan nabi. (2). Saya tadi pagi ceramah di depan TNI, Mau 'ngebully' TNI, gimana nggak bisa. (3). Saat umar lewat sebuah jalan, maka setan takut semua. 'Google map' yang dilewati Umar jadi merah semua, 'forbidden' buat setan. (4). Saat kaum kafir menantang nabi untuk membelah bulan. Rasul berkata: "Apakah kalau saya membelah bulan, apakah kalian mau beriman?" jawab kaum kafir" ya. 'Posting' aja dulu pokoknya". (5). Ali meminta izin kepada Rasulullah untuk menerima tantangan duel Amru. Izinkan saya untuk 'report', biar di'block' sama 'instagram'.

Some sentences that may be difficult to understand by old parents are: (1). Commentnya para sahabat positif. Tidak 'nge-bully' nabi saat nabi lupa jumlah rakaat shalat. Karena mereka 'followers' yang matang, bukan follower yang 'labil'. Tidak bikin 'hastag' \#nabi lupa dan di'viral'kan. (2). Nabi sangat 'low profile'. 'Easy going', 'no hardfeeling'. (3). Kita di'mention'. Buat buku 100 'rapor merah' suami. (4). Aisyah 'stalking', 'ngepoin postingan' sofiya. Sofiya lagi 'insta story' apa ini? Sofiya lagi 'garden party', 'barbeque'-an. Sofiya itu 'humble'. (5). Rasul mengejar Aisyah seperti 'drakor' gitu deh. (6). Hafshah meng'capture' 'chat' Nabi dan di'forward' ke Aisyah. Aisyah posting dengan 'hastag' demi tuhan Ibrahim. Bukan demi Tuhan Muhammad. Allah 'DM' Nabi. Hafshah bersekongkol dengan Aisyah.

\section{E. Conclusion}

Based on the research results, it can be concluded that Hanan Attaki's Millennial Da'wah is aimed to the Millennial generation. The material of Hanan Attaki's da'wah is more about morals, rather than on fiqh. The language used in the da'wah of ustadz hanan Attaki is youth slang. In this research, the author revealed 4 videos of Ustadz Hanan Attaki's millennial da'wah which were uploaded on the YouTube channel Kajian Islam News, Motive Islam, Kajian Islam Harian, and Dunia Bumi. The values of character education in the millennial da'wah of Ustadz Hanan Attaki can be seen in the four videos, namely: respect for others, be brave, be wise, gentle, be patient, be humble, not arrogant, accepting other people's advice, be encouraged to admit mistakes, and low profile.

Furthermore, the strength of the millennial da'wah of Ustadz Hanan Attaki is that it is very acceptable for young people or the millennial generation, a generation born in the 1980s to 2000s. While the weakness of Ustadz Hanan Attaki's millennial da'wah is that the recipients of da'wah tend to be only young people, or modern people. Parents who are not modern cannot follow the style of the lecture of Ustadz Hanan Attaki. Hanan Attaki often uses contemporary 
terms that old parents do not understand. This research is still limited to the 4 YouTube videos of Hanan Attaki for the millennial generation. There are many other videos from Hanan Attaki and contain various other materials besides character education.

\section{References}

Afandi, M. Kajian Material dan Kajian Formal Dakwah. Proceedings of International Conference on Da'wa and Communication 1, no. 1 (2019): 467-475.

Ainiyah, Nur. "Pembentukan Karakter Melalui Pendidikan Agama Islam", Al-Ulum, no. 1 (2013).

Akbar, S., Samawi, A., Arafiq, M., \& Hidayah, L. Model Pendidikan Karakter yang Baik di SD (Studi Lintas Situs Best Practices). Jurnal Sekolah Dasar Kajian Teori Dan Praktik Pendidikan 2, no. 2 (2014): 139-151.

Arif, M. C., \& Fitriyah, R. D. Domestikasi Teknologi Informasi dan Komunikasi Keluarga Muslim di Kampung Cyber Surabaya. Proceedings of International Conference on Da'wa and Communication 1, no. 1 (2019): 148-158.

Baroroh, U. (2019). Metode dan Materi Dakwah untuk Wanita Bermasalah. Jurnal Ilmu Dakwah, 38(2), 267. https://doi.org/10.21580/jid.v38.2.3888

Brata, D. P. N. Pengembangan Pendidikan karakter melalui Pembelajaran Kooperatif. Prosiding Seminar Nasional Rekonstruksi Kurikulum dan Pembelajaran di Indonesia Menghadapi Masyarakat Ekonomi Asean 2, no. 1 (2016): 23-24.

Chozin, M. A. "Strategi Dakwah Salafi di Indonesia." Jurnal Dakwah 14, no. 1 (2013): 1-25.

Devi. Berdakwah di Era Milenial (Modern). (n.d.).

Dulwahab, E. Dakwah di Era Konvergensi Media. Jurnal Ilmu Dakwah 5, 16 (2010): 19-34.

Farida. Strategi Pengembangan Materi Dakwah Tokoh Agama di Desa Loram Wetan ( Tinjauan Psikologis Mad ' U ). AT-TASYBIR, Jurnal Komunikasi Penyiaran Islam 1, no. 1 (2013): 45-74.

Farihah, I. Strategi Dakwah di Tengah Konflik Masyarakat. ADDIN 8, no. 2 (2014): 295-318.

Firousyurahman, M. "Da'wah and Interpersonal Attraction of Popular Figure in Indonesian Television. Ilmu Dakwah: Academic Journal for Homiletic Studies 12, 12, no. 2 (2018): 259274. https://doi.org/10.15575/idajhs.v12i1.6174

Hakim, L., \& Meidayanti, A. Implementasi Jurnalisme Dakwah dalam Media Online Islam: Analisis Isi Berita VOA-Islam.com. Jurnal Komunikasi Islam 10, no. 1 (2020): 173-193. https://doi.org/10.15642/jki.2020.10.1.173-193

Hasanah, A. Pengembangan Karakter Berbasis Kearifan Lokal pada Masyarakat Minoritas. Analisis XII (2012): 209-229.

Hasanah, H., Hadjar, I., \& Bukhori, B. (2018). Development of Campus Da ' i Cadre Competency Model: Psychology and Management Approach. Ilmu Dakwah, 12(2), 229-246. https://doi.org/10.15575/idajhs.v12i1.4536

Hayati, F. Pendidikan Karakter Berbasis Islam. Ta'dib: Jurnal Pendidikan Islam 7, no. 1 (2018): 67-74. https://doi.org/10.29313/tjpi.v7i1.3764

Kristina, A. Dakwah Digital Untuk Generasi Milenial : Studi Atas Praktik Dakwah Di Komunitas Omah Ngaji, Surakarta. Iain Surakarta 5 (2019). https://iain-surakarta.ac.id/dakwahdigital-untuk-generasi-milenial-studi-atas-praktik-dakwah-di-komunitas-omah-ngajisurakarta/

Kurniati, K. Peluang dan Tantangan Majelis Taklim pada Era Teknologi Informasi Ditinjau dari Perspektif Sosiologi Dakwah: Studi Kasus Majelis Taklim Jabal Al-Rahma di Perumahan 
Bukit Lawang Indah. Proceedings of International Conference on Da'wa and Communication, 1, no. 1 (2019): 118-133.

Mas'udi. Dakwah Kontemporer dalam Bingkai Dakwahtainment (Kajian Popularitas Instan Pelaku Dakwahtainment 4, no. 2 (2016): 323-338.

Muhaemin, E. Dakwah Digital Akademisi Dakwah. Ilmu Dakwah: Academic Journal for Homiletic Studies 11, no. 2 (2017): 341-356. https://doi.org/10.15575/idajhs.v11i2.1906

Muhamadi, S., \& Hasanah, A. Penguatan Pendidikan Karakter Peduli Sesama Melalui Kegiatan Ekstrakurikuler Relawan. Jurnal Pendidikan Agama Islam, 16 no. 1 (2019): 95-114. https://doi.org/10.14421/jpai.2019.161-06

Munjiat, S. M. Peran Agama Islam Dalam Pembentukan Pendidikan Karakter Usia Remaja. AlTarbawi Al-Haditsah: Jurnal Pendidikan Islam 3, no. 1 (2018): 170-190. https://doi.org/10.24235/tarbawi.v3i1.2954

Naqqiyah, M. S., \& Nurdin, A. Credibility of Islamic Preachers in the Post-Truth Era: A Study of Da'i in Surabaya. Ilmu Dakwah: Academic Journal for Homiletic Studies 13, no. 2 (2019): 271-290. https://doi.org/10.15575/idajhs.v13i2.6725

Nurdin, A. The Use of Social Media Digital Native and Digital Immigrant Muslim Generation in Surabaya. Proceedings of International Conference on Da'wa and Communication 1, no. 1 (2019): 134-147.

Rahman, F. Digital Media Literacy for the Better Santri: Reconsidering the Power of Internet for the Students of Traditional Pesantren. Proceedings of International Conference on Da'wa and Communication 1, no. 1 (2019): 110-118.

Saepullah, U., \& Muchtar, K. E-Dakwah Islam Digest Republika.Co.Id. di Indonesia. Ilmu Dakwah: Academic Journal for Homiletic Studies 14, no. 1 (2020): 39-54. https://doi.org/10.15575/idajhs.v14i1.8678

Sajadi, D. Problematika Dakwah Kontemporer Tinjauan Faktor Internal dan Eksternal (n.d.): 93-.

Salsabilah. "Pendidikan Karakter Islami Berbasis Nilai-Nilai Kearifan LokaL (Penelitian di SDN 12 Ciseureuh Kahuripan Pajajaran Purwakarta)." Cendekia 17, no. 2 (2019): 269-284.

Shidiq, A. F., \& Raharjo, S. T. Peran Pendidikan Karakter di Masa Remaja sebagai Pencegahan Kenakalan Remaja. Prosiding Penelitian dan Pengabdian kepada Masyarakat 5, no. 2 (2018): 176. https://doi.org/10.24198/jppm.v5i2.18369

Sugara, R., Sari, P. A., Muhsin, M., \& Attahira. Metode Dakwah Al Mauidza Hasana di Era Milenial. January 5 (2019).

Suyatno, Jumintono, Pambudi, D. I., \& Mardati, A. Strategy of Values Education in the Indonesian Education System. International Journal of Instruction 12, no. 1 (2019): 607-624.

Suyatno, M., Jumintono, M., Pambudi, D. I., \& Mardati, A. Design of Values Education in School For Adolescents. International Journal of Instruction, 134 (Icirad) (2017): 10-13. https://doi.org/10.2991/icirad-17.2017.2

Thaib, E. J. Da'wa, Social Media and Challenge the mainstream of Islam Among Millenial Generation. Proceeding of International Conferrence on Da'wa and Communication 1, no. 1 (2019): 101-109.

Walian, A. Pengembangan Media Dakwah Kontemporer Berbasis Website: Studi Kasus pada WWW. Assajidin. Com. Jurnal Komunikasi Islam dan Kehumasan (JKPI), 3 (2019): 1-21. http://jurnal.radenfatah.ac.id/index.php/JKPI/article/view/4260 
Vol. 2 No. 1, 2020

Windiatmoko, D. uji, \& Mardliyah, A. A. Refleksi Kultural dan Pendidikan Karakter dalam Tradisi Ruwahan di Dusun Urung Urung. Matapena: Jurnal Keilmuan Bahasa, Sastra, Dan Pengajarannya 1, no. 2 (2018): 1689-1699.

Zuchdi, D., Prasetya, Z. K., \& Masruri, M. S. Pengembangan Model Pendidikan Karakter Terintegrasi dalam Pembelajaran Bidang Studi di Sekolah Dasar. Cakrawala Pendidikan, XXIX, no. 3 (2010): 1-12. https://doi.org/10.21831/cp.v1i3.224

\section{Acknowledgment}

Nasihatul Latifah, Lilik Huriyah, Rohil Zilfa are aothors. Nuwailah Rohmah Rufqoti is the translator. 